\title{
Konya Mutfağında Yer Alan Yöresel Yemeklerin İşletme Menülerinde Yer Alma Düzeylerinin Tespit Edilmesi
}

\author{
Determination of the Inclusion Levels of Regional Konya Cuisine in the Business \\ Menus
}

\author{
Dr. Öğr. Üyesi Yılmaz SEÇİM (iD) 1 , Y1. Öğr. Mehmet Fatih ESEN (iD) 2
}

\begin{abstract}
$\ddot{\mathbf{O} z}$
İnsanların farklı kültürlerin yemeklerini keşfetme isteği günden güne yaygınlaşarak gastronomi turizminin popülerliğini artırmaktadır. Gastronomi turizminin popülerliğini artırmasıyla yöresel mutfaklara verilen önem de artmıştır. Konya, zaman içinde yöresel mutfağın yansıtılldı̆̆ önemli gastronomi destinasyonlarından biri haline gelmiştir. Gelişen gastronomi turizmi sonrasında Konya ilinde bu araştırmanın yapılması gerekliliği ortaya çıkmıştır. Yapılan araştırmada anket tekniği kullanılmış ve toplam 60 işletmenin menüsü incelenmiştir. Anket çalışmasında söz konusu restoranların hizmet yıll, faaliyet alanı, personel sayısı ve Konya mutfağına ait yöresel yemeklerin menülerinde yer alıp almadığına dair sorular sorulmuştur. Araştırma sonucunda Konya mutfağına özgü olan bamya çorbası, etliekmek, firın kebabı, tirit, sac arası tatlısı ve höşmerim tatlılarının menülerde bulunduğu tespit edilmiştir. Bu ürünler dışında Konya mutfağına ait olan birçok yemek ve tatlının ise menülerde yer almadığı tespit edilmiştir. Özellikle halkın geniş bölümü tarafından sevilerek tüketilen toyga çorbası, tarhun otu çorbası, kikirdekli kesme çorba, zülbiye, etli su böreği gibi lezzetlerin sadece halk arasında değil işletmelerde yerli ve yabancı turiste sunulması faydalı olacaktır. Konya gastronomi turizminin gelişmesi için; yerli ve yabancı turistin damak tadına uyacak lezzetlerin ortaya çıkarılarak menülerde yer alması önem taşımaktadır. Unutulan lezzetlerin menülerde yer alması konusunda sektör ve üniversite iş birliği büyük önem taşımaktadır.
\end{abstract}

Anahtar Kelimeler: Gastronomi, Konya mutfağı, menü, yöresel mutfak

Makale Türü: Araştırma

\begin{abstract}
The desire of people to discover the food of different cultures is spreading day by day, increasing the popularity of gastronomic tourism. After the development of gastronomic tourism, the need for this research has emerged in Konya province. The survey technique was used and a total of 60 business menus were examined. As a result of the research, it was found that okra soup, etliekmek, firın kebab, tirit, sacaras1 dessert and höşmerim desserts which are unique to Konya cuisine were found in the menus. Apart from these products, it was found that many dishes and desserts belonging to Konya cuisine are not included in the menus. In particular, it will be beneficial to present the delicacies such as toyga soup, tarragon soup, kikirdekli cut soup, zülbiye, and meat water rolls, which are loved and consumed by the large part of the public, not only among the public but also to the domestic and foreign tourists. For the development of Konya gastronomy tourism; It is important that local and foreign tourists find the tastes that fit the palate and take place in the menus. Collaboration between the sector and the university is of great importance for the forgotten tastes to be included in the menus.
\end{abstract}

Keywords: Gastronomy, Konya cuisine, menu, local cuisine

Paper Type: Research

\footnotetext{
${ }^{1}$ Necmettin Erbakan Üniversitesi, Turizm Fakültesi, yilmazsecim@ gmail.com.

${ }^{2}$ Necmettin Erbakan Üniversitesi, Turizm Fakültesi, esen1919@hotmail.com.
}

Atıf için (to cite): Seçim, Y. ve Esen, F.M. (2019). Konya mutfağında yer alan yöresel yemeklerin işletme menülerinde yer alma düzeylerinin tespit edilmesi. Afyon Kocatepe Üniversitesi Sosyal Bilimler Dergisi, 22(1), 279-294. 


\section{Giriş}

İnsanların yaşamlarına devam edebilmesi için beslenme en temel ihtiyaçtır (Kurnaz ve İşlek, 2018, s. 50). İlk çağlarda insanlar beslenme gereksinimini avcıllk- toplayıcıllk faaliyetleri ile gerçekleştirmiştir. Bu durum insanların gıdaya ulaşmasını zorlaştırmıştır. Özellikle ateşin bulunması ve yerleşik hayata geçilmesi beslenme çeşitliliğini artırmıştır. İnsanlar dügün, ölüm gibi özel günlerinde dostlarına farklı yemekler sunarak gastronomi kültürünü zaman içinde geliştirmişlerdir. (Özel, Yıldız ve Akbaba 2017, s. 352). Gastronomi genel anlamda yeme-içme faaliyetlerinin tümü yani yemek yeme sanatıdır (Seyitoğlu ve Çalışkan, 2014, s. 24). Yemek yeme olayının zevk haline geldiği günümüzde en iyi ve en güzel yemeği bulma araştırmaları gastronominin gelişiminin her geçen gün devam ettiğinin bir göstergesidir. İnsanların kendi kültürleri dışında başka bir mutfak kültürüne ait olan yiyecek-içecekleri denemesi, yeme içme alışkanlıklarını gözlemlemesi ve yemeğin pişirilmesi, sunumu gibi aktivitelere katılması gastronomi turizmi olarak tanımlanmaktadır (Kılınç ve Kılınç, 2018, s. 395). Teknolojinin ilerlemesi ve ulaşımın kolaylaşmasıyla birlikte turistlerin belirli bölgelere özgü yiyecekleri, kendine has pişirme ve servis yöntemleri ile yerinde tatma duygusu gastronomi turizmini ortaya çıkarmıştır (Kurnaz ve İşlek, 2018, s. 50). Gastronomi turizmi kapsamında özel bir yemeği denemek, yemeğin yapım aşamalarını izlemek, alanında ünlü olan bir şefin hazırladığı yemeği tatma gibi etkinlikleri yer alır (Kılınç ve Kılınç, 2018, s. 395). Son yıllarda turistler deniz, kum, güneş üçlüsünü terk ederek farklı mutfak ve halk kültürlerini keşfetmek amaciyla seyahat etmektedir. Seyahat edilen destinasyonlar sahip oldukları yerel mutfağı çekim gücü olarak kullanmaktadırlar (Mil ve Denk, 2015, s. 2). Turistlerin gidecekleri destinasyonun seçiminde bu çekici unsurlar etkili olmaktadır (Cömert, 2014, s. 65). Turistler gittikleri destinasyonlarda konaklama, yeme içme, alışveriş, seyahat etme, halkla iletişim kurma gibi aktivite gerçekleştirmektedir. Turistlerin tekrar aynı bölgeyi tercih etmesi için hizmet kalite standartlarını üst seviyede tutulması gerekmektedir (Mil ve Denk, 2015, s. 2). Gastronomi turizmini tüm bölgeyle bütünleştirmenin en iyi yolu yerel ürünlerin, yerel yemeklerin veya yöreye ait olan içeceklerin o bölgedeki oteller ya da restoranların menülerinde yer almasıdır (Mil ve Denk, 2015, 2).

Türkiye farklı milletlere ait birçok etnik grubun uzun yıllar bir arada yaşadığı ve kültürlerini koruyarak Türk mutfak kültürünü zenginleştirdiği bir ülkedir. Bu özelliği nedeniyle; Türkiye, gastronomi turizmi açısından oldukça büyük bir potansiyele sahiptir (Şen ve Silahşör, 2018, s. 417). Türk mutfağı, Dünya mutfakları arasında en zengin mutfaklardan biri olarak görülmektedir. Türk mutfağında yapılacak doğru tanıtım ve iyi imaj çalışmaları markalaşma düzeyinde artış sağlayacaktır (Cömert, 2014, s. 65). Türk mutfağının özünde ve ortaya çıkmasında Türk tarihi, ülkenin coğrafi konumu ve diğer medeniyetlerle ilişkisi ön plana çıkmaktadır. Türkiye'deki her bölgenin değişen özellikler ve farklı hayat koşulları yöresel mutfakları oluşturmuştur. Yöresel mutfak tanımı bir bölgede yetişen ürünler ve halkın kültürüyle iç içe geçerek oluşturulan, gelenek haline gelmiş yiyecek ve içecekler olarak tanımlanabilir (Hatipoğlu, Zengin, Batman ve Şengül, 2012, s. 7). Yöresel mutfağın oluşumunda gelenek, görenek, dini ve milli etkiler, iklim koşulları, mevsimsel değişiklikler, coğrafi yapı, nesilden nesile aktarılan bilgi birikimi ve yöreye ait yiyecek içecekler yöresel mutfağın oluşumunda ki ana unsurlardır (Kurnaz ve İşlek, 2018, s. 50). Her bölgede kendine has olan bu yiyecek ve içecekler özellikle bayramlar, dügünler ve özel günlerde hazırlanıp sofralarda yer almaktadır. Yöresel yemekleri diğerlerinden ayıran özelliklerin başında kendine has teknikler ve sunumların kullanılması gelmektedir. $\mathrm{Bu}$ teknik ve sunumlar yörenin turistler tarafindan diğer destinasyonlardan farklı olarak algılanmasını sağlamaktadır (Aslan, Güneren ve Çoban, 2014, s. 5). Türkiye'de her bölgenin kendine özgü yemekleri ve yeme alışkanları vardır. İç Anadolu mutfağ 1 Türk mutfak kültürünü doğrudan yansıtan en önemli mutfaklardan birisidir. Bölgenin mutfak kültüründe iklime ve coğrafi özelliklere bağlı olarak tahıl ürünlerine dayalı hamur işleri başta gelmektedir. Bölge mutfağında küçükbaş hayvan eti, yoğurt ve sebzeler önemli bir yer tutmaktadır (Büyükşalvarc1, Şapçılar ve Y1lmaz, 2016, s. 167). 


\section{Konya Mutfağı}

Tarihte Konya çevresinde iskân MÖ. 7000-9000 yıllarına kadar gitmektedir. Konya merkezinde ise iskânın, MÖ 1000'lerden itibaren başladığı ve MÖ. 300 yılından itibaren hızlı bir gelişme gösterdiği bilinmektedir (Mehmet, 1971, s. 15). Geçtiğimiz yıllarda yapılan kazı çalışmalarında Çatalhöyük'te bulunan mutfak araç, gereçleri ve mercimek ve bulgur gibi ürünler yaklaşık 8000 yıldır Konya ve çevresinde yemekle uğraşıldığını kanıtlar niteliktedir. Kazılarda mercimek ve bulgur gibi ürünlerin bulunması günümüzde Konya'da halen sevilerek yenilen mercimek yemeği, tandır çorbası, bulgur pilavı gibi yemeklerin köklerinin eskiye dayandığının kanıtıdır (Seçim, 2018, s. 198). Selçuklu devletine başkentlik yapan Konya aynı zamanda Mevlâna Hazretleri aşçıbaşı Ateş-Bâz-1 Veli gibi bir aşçıbaşına ev sahipliği yaptığından dolayı hayli zengin olan bir mutfak kültürünü oluşturmuştur (Halıcı, 2008, s. 118).

Mevlevilikte mutfak, Matbah veya Matbah-1 Şerif adıyla bilinen ve günümüzde mutfak ismiyle tabir edilen bölüm, eğitimin başladığı kutsal bir makam olarak kabul edilmiştir (Alptekin, 2007, s. 3, Bekleyiciler, 2007, s. 31). Mevleviler malzeme ve pişirme yöntemine göre yemeğe birçok sembolik anlam ve dini motif yüklemiştir. Yiyeceklerin en verimli şekilde kullanılmasına ve tüketilmesine büyük önem vermişlerdir (Aksoy, İflazoğlu ve Bulut. 2016 s. 101). Mevlevi mutfağının en bilinen yemekleri Tutmaç Çorbası, Toyga Çorbası, Zülbiye, Bulgur Aşı, Pekmezli Ayva Yemeği, Pekmezli Havuç Yemeği, Kereviz Kalyesi, Bulamaç Aşıdır. Bu yemekler dışında dergâhta kesinlikle haram olan yiyecekler ve balık tüketilmezdi. Balık tüketilmemesinin sebebinin dergâhta oluşacak kokudan rahatsız olunması ihtimali olduğu düşünülmektedir (Bekleyiciler, 2007, s. 89, Ertaş, vd. 2017, s. 59).

Türk kültüründe mutfak sadece yemek pişirilen bir mekân değil ev ahalisinin oturup dinlendiği ve sohbet ettiği yerdir. Türk insanı Orta Asya'dan Anadolu'ya taşıdığı mutfak kültürü ve lezzetini Anadolu'nun birikimiyle zenginleştirmiştir. Konya mutfağ 1 da zaman içerisinde değişen ve gelişen bir mutfak olmuştur (Ögel,1978, s. 41, Odabaşı 2001, s. 12). Fetihten sonra Selçuklu Türkleri Konya'da çok fazla ikamet etmemiştir. Konya'da o dönemde daha çok asker aileleri kalmıştır. Anadolu'ya gelen nüfus Kafkaslardan ve yakın doğudan gelirken yemek kültürünü de beraberinde getirmiştir. Beraberinde getirdikleri önemli ürünler arasında ekmek, Oğmaç ve tutmaç gibi önemli yemek çeşitleri bulunmaktadır. Anadolu'ya yerleşen nüfus Konya ve çevresinde yetişen sebze, meyve ve otlardan yeni yemekler yapmışlar ve bu yemekleri Konya yemek kültürüne kazandırmışlardır. Amerika'nın keşfinden sonra dünyaya yayılan domates ve patates ise Osmanlı devletinin son döneminde Konya mutfağında kullanılmıştır (Odabaşı,2001, s. $18)$.

1950'li yıllara kadar Konya mutfağında en çok kullanılan etin koyun ve tiftik keçisi eti olduğu bilinmektedir. Yağlı et sevenler tarafindan koyun eti daha çok tercih edilirken, Yağsız et tüketenler ise tiftik keçisi etine talep göstermiştir. Kuzu ve dana eti ise pek talep görmemiştir (Işık, 2006). Konya halkı tarafından et kebaptan ziyade tencere yemeklerinde kullanılmıştır. Konya mutfağında tercih edilen bir et ürünü değildir. Kıyma sadece dolma, sarma ve köftelerde kullanılmıştır. Sebze yemeklerinde özellikle patlıcan ve taze fasulye kullanılmıştır (Odabaşı, 2001, s. 20). Mutfakta ekmek önemli yer tutmaktadır. Ekmek eskiden her evin kendine ait olan tandırında yaptığı bir yiyecektir. Haftanın belirli günlerinde ekmek yapmak için tandır yakılır, ekmek yapıldıktan sonra ise tandırın içine salınan çömlek veya tencerelerde tandıra özgü yemekler pişirilirdi. Bu yemeklerin başında ise tandır çorbası ve kelle-paça gelmektedir. Tandırda yapılan ekmek sadece yemeklerin yanında katık olarak kullanılmamış aynı zamanda bazı yöresel yemeklerin yapımında da kullanılmıştır. Bu yemeklerden bazıları; tirit, papara, sündürme, ekmek salması, ekmek oğması, patlıcan tiridi, paça tiridi, kedi tirididir. (Odabaşı, 2001, s. 46, Özkafa, 2010). Konya mutfağında kullanılan diğer malzemelerin başında ise süzme yoğurt, reyhan, terhun, düğü (ince bulgur) gelmektedir (Büyükşalvarc1, vd. 2016, s. 167). 


\section{Yöntem}

$\mathrm{Bu}$ araştırma, Konya ilinde faaliyet gösteren restoranların menülerinde yöresel yiyecek ve içeceklerin yer alma düzeylerinin tespit edilmesi amacıyla yapılmıştır. Araştırma Konya il merkezinde bulunan işletmelere uygulanmıştır. Konya merkez ilçeleri olan Selçuklu, Karatay ve Meramda bulunan toplam 60 restoran çalışmaya dâhil edilmiştir. Anket çalışması 2018 yılının Ağustos-Kasım ayları arasında yapılmıştır. Araştırma yapılacak işletmelerin çalışmaya katılım istekleri sayının belirlenmesini sağlamıştır.

Araştırmada durumun değerlendirilmesine olanak sağlayan verilerin toplanabilmesi amacıyla 'Anket tekniği' kullanılmıştır. Anket, birincil kaynaklardan bilgi toplamak amacıyla hazırlanmış belirli bir sistemi olan soru formudur. Anket yapmanın amacı, yapılan araştırmanın problemini çözecek ve ele alınan hipotezleri test edecek bilgileri sistemli bir şekilde toplayıp saklamaktır. Bu çalışmada anket tekniğinin çeşitlerinden olan yüz yüze anket tekniği uygulanmıştır. Görüşme cetveli cevaplayan kişiye başka soru sormayı gerektirmeyecek şekilde hazırlanmıştır (İslamoğlu ve Alnıaçık, 2016).

Anket çalışmasında söz konusu restoranların hizmet yılı, faaliyet alanı, personel sayısı ve Konya mutfağının yöresel yemeklerinin menülerinde yer alıp almadığına dair sorular sorulmuştur. Çalışmada anket soruları hazırlanırken literatür incelemesi yapılmış, ilgili kaynaklar incelenmiş, Konya mutfak kültürü hakkında deneyimli kişilerden bilgiler alınmıştır.

\section{Literatür İncelemesi}

Konya mutfağı, farklı pekçok kültüre ev sahipliği yapması nedeniyle zengin bir yemek çeşitliliği kazanmıştır. Ancak bu zengin yemek kültürü dönem içinde unutulmuştur. Konya gibi farklı yörelerinde zengin yemek kültürünün unutulduğu görülmektedir. Unutulan değerlerin yeniden gün yüzüne çıkarılması ve gastronomi turizmine kazandırılması amacıyla yöresel mutfaklar üzerine farklı çalışmalar yapıldığı görülmektedir. Yapılan literatür taramasında yöresel mutfaklar hakkında yapılan ulusal ve uluslararası çalışmalar incelenmiştir

Hatipoğlu, Zengin, Batman ve Şengül (2012) tarafindan Gelveri bölgesinde yapılan çalışma, restorasyon sonrası turizm işletmesi olarak hizmet veren işletmeler üzerinde uygulanmıştır. $\mathrm{Bu}$ araştırma sonucunda araştırma konusu işletmelerin menülerinde yöresel yemeklerin hangi oranda kullanıldığını tespit etmişlerdir. Yöresel yemek üretiminde Gelveri ilçesinde yöresel yemeklere menülerde çok fazla yer verilmediği tespit edilmiştir.

Kızılırmak, Albayrak ve Küçükali (2014) tarafından yapılan çalışmada Trabzon Uzungöl'de bulunan işletmelerin menüleri üzerinde doküman incelemesi yapılmış ve Trabzon mutfağının işletmelerde kullanım oranını tespit etmişlerdir. Menülerde yöresel yemeklere özgü bir bölüm açılmadığını tespit etmişılerdir.

Aslan, Güneren ve Çoban (2014) tarafından yapmış oldukları çalışmada Nevşehir mutfağının, bölge turizminde çekici bir unsur olup olmadığının saptanması ve yöresel mutfağın bölgenin markalaşmasına etkisini belirlemeyi amaçlamışlardır.

Cömert (2014) tarafindan yapılan çalışmada Hatay ilinin yöresel yemekleri incelenmiş ve yöresel yemeklerden örnekler sunulmuştur. Bu çalışmada yöresel yemeklere sahip çıkılması gerektiği vurgusu yapılmıştır.

Mil ve Denk (2015) yapmış oldukları çalışmanın amacını Erzurum Palandöken ilçesinde bulunan otellerin menülerinde kullanılan yöresel ürünleri belirlemek olarak bildirmişlerdir. Çalışmada sonucunda otellerin yöresel yemekleri menülerinde az miktarda kullandıkları ancak ulusal veya uluslararası ürünlere bol miktarda yer verdiklerini tespit etmişlerdir.

Zağralı ve Akbaba (2015) yapmış oldukları çalışmada İzmir Yarımada'sını ziyarette bulunan turistler açısından yöresel yemeklerin destinasyon tercihi üzerinde rol oynayıp oynamadığı araştırılmıştır. Yapılan araştırma sonucunda turistlerin tercihlerinde yöresel 
yemeklerin belirleyici bir rol oynamadığı sonucuna varmışlardır. Fakat konaklamaları esnasında yedikleri yöresel lezzetleri beğendiklerini ifade etmişlerdir.

Cömert ve Özata (2016) yapmış oldukları çalışmada tüketicilerin, menülerde yöresel mutfak ürünleri bulunan işletmeleri tercih etme nedenlerini Karadeniz mutfağ incelemişlerdir. Araştırma sonucuna göre yöre mutfağına ilginin yüksek olduğu sonucuna varmışlardır.

Büyükşalvarcı, Şapcılar ve Yılmaz (2016) yapmış oldukları çalışmada Konya yöresel yemeklerinin restoranlarda kullanılma durumunu ortaya koymuşlardır. Çalışmada Konya mutfağına ait yöresel yemeklerin, işletmeler tarafından tercih edilmediği veya diğer yemeklere oranla daha az tercih edildiği sonucuna ulaşılmıştır.

Özel, Yıldız ve Akbaba. (2017) Kilis ilinde bulunan 11 farklı işletmede üzerinde, Kilis yöresel yemeklerinin menülerde yer alma düzeylerinin belirlenmesi amaciyla yapılmıştır. Çalışma sonucunda işletmelerin menülerinde yöresel yemeklere fazla yer verilmediği saptanmıştır.

Arıkan (2017) yapmış olduğu çalışmada, Eskişehir mutfağına özgü yöresel yemeklerin, Eskişehir'de faaliyet gösteren restoran menülerinde bulunma sıklığını tespit etmeyi amaçlamıştır. Araştırma sonucunda yöresel yemeklerin pek çoğunun işletme menülerinde yer almadığ1 sonucuna ulaşılmıştır.

Yeşilyurt, Yeşilyurt, Güler ve Özer (2017) yapmış oldukları çalışmada Adıyaman ilinde bulunan otel işletmelerinin menülerinde yöresel yemeklerin bulunma durumunu tespit etmeyi amaçlamıştır. Çalışma sonucunda, işletmelerin menülerinde yöresel yemeklerin bulunmadığ sonucuna ulaşılmıştır.

Erdem, Mızrak ve Kemer (2018) yapmış oldukları çalışmada kırsal bir yerleşim yeri olan Mengen'in yöresel yemeklerinin Mengen de ki yiyecek-içecek işletmelerinin menülerinde hangi oranda yer verildiğini araştırmışlardır. Çalışmada yöresel yemeklerin işletmeler tarafından tercih edilmediği tespit edilmiştir.

Kurnaz ve İşlek (2018) tarafından yapılan çalışmada Marmaris ilçesinde yer alan işletmelerin menülerinde kullanılan yöresel yemeklerin belirlenmesi amaçlanmıştır. Bölgede bulunan işletmelerin menüleri değerlendirmeye alınmış ve analiz edilmiştir. Araştırma sonucunda Marmaris yöresel yemeklerinin işletme menülerinde fazla yer bulamadığı belirlenmiştir.

Şen ve Silahşör (2018) Erzincan ilinde bulunan 17 yiyecek ve içecek işletmesinde yöresel yemeklerin menülere yansımalarını incelemiştir. Çalışma sonucunda işletmelerin önemli bir çoğunluğunun yöresel ürünlere menülerinde yer verdiği görülmüştür.

Ceylan ve Güven (2018) yapmış oldukları çalışmada Kütahya yöresel yemeklerinin işletmelerin menülerinde yer alma durumunu değerlendirmiştir. Araştırma sonucunda yiyecek içecek işletmelerinin yöresel yemeklerin büyük bölümünü bildiği fakat menülerinde bu yemeklere sürekli yer vermediği anlaşılmışıır.

Kılınç ve Kılınç (2018) yapmış oldukları çalışmada Batı Akdeniz Mutfağı mutfağına ait olan yöresel yiyecek ve içeceklerin işletmelerin menülerinde yer alma düzeylerine tespit etmeyi amaçlamışlardır. Araştırma sonucunda yabancı mutfak ürünlerinin oransal olarak ulusal mutfak ürünlerimizden daha fazla kullanıldığı tespit edilmiştir. 


\section{Bulgular ve Tartışma}

Tablo 1. İşletmelerin personel sayısı

\begin{tabular}{lllll}
\hline Personel sayısı & Bölge & & & \% \\
\hline & Selçuklu & Karatay & Meram & \\
$\mathbf{1 - 5}$ & 3 & 5 & 4 & 20 \\
$\mathbf{6 - 1 0}$ & 5 & 7 & 4 & 26,7 \\
$\mathbf{1 1 - 1 5}$ & 6 & 3 & 7 & 26,7 \\
$\mathbf{1 6}$ ve üzeri & 6 & 5 & 5 & 26,6 \\
Toplam & 20 & 20 & 20 & \\
\hline
\end{tabular}

Araştırmaya dâhil olan işletmelerin personel sayısı incelendiğinde 11 ve üzerinde personel sayısına sahip olan işletmelerin \%50 den fazla olduğu görülmektedir. Kalan işletmeler ise 10 ve altında personel çalıştırmaktadır. İşletmeler kalite ve hizmet anlayışının geliştirdikçe personel sayısında artış meydana gelmektedir. Bu anlayışa göre işletmelerin yarısından fazlası kalite ve hizmet anlamında tanınan işletmeler arasında gösterilebilir.

Tablo 2. İşletmelerin hizmet yılı

\begin{tabular}{llccc}
\hline Hizmet Yılı & Bölge & & & Meram \\
\hline & Selçuklu & Karatay & 10 & 28,2 \\
$\mathbf{1 - 5}$ & 3 & 4 & 2 & 13,4 \\
$\mathbf{6 - 1 0}$ & 4 & 2 & 2 & 15,0 \\
$\mathbf{1 1 - 1 5}$ & 4 & 3 & 6 & 43,4 \\
$\mathbf{1 6}$ ve üzeri & 9 & 11 & 20 & \\
Toplam & 20 & 20 & & \\
\hline
\end{tabular}

Konya merkez ilçe olarak Karatay, Meram ve Selçuklu ilçelerinden oluşmaktadır. Bu ilçeler gerek turizm gerekse sosyal alan açısından zengin bölgelerdir. Konya yöresel yemeklerinin işletmelerde üretim oranlarının tespit edilmesi için hazırlanan bu çalışmada 20'şer adet Selçuklu, Meram ve Karatay bölgesinde bulunan işletme çalışmaya dâhil edilmiştir. Bu işletmelerin hizmet yılı incelendiğinde 16 ve üzeri hizmet yılına sahip işletme oranı \%43,3 olarak tespit edilmiştir. Yiyecek-içecek sektöründe uzun y1llar hizmet edebilen işletmeler kalite ve hizmet anlayış1 gelişmiş işletmeler olarak algılanmaktadır.

Tablo 3. İşletmelerin faaliyet alanı

\begin{tabular}{lllll}
\hline Faaliyet Alanı & & Bölge \% & \\
\hline & Selçuklu & Karatay & Meram & \\
Sulu Yemek & 3 & 1 & 4 & 13,4 \\
Konya Mutfağı & 1 & 13 & 2 & 26,6 \\
Kebap/Etliekmek & 10 & 5 & 10 & 41,7 \\
$\begin{array}{l}\text { Salonu } \\
\text { Diğer }\end{array}$ & 6 & 1 & 4 & 18,3 \\
Toplam & 20 & 20 & 20 & \\
\hline
\end{tabular}

Araştırmaya katılan işletmelerin çoğunun $(\% 41,6)$ Kebap/Etliekmek salonu olarak faaliyet gösterdiği bunu \%26,6 oranla Konya mutfağı alanında faaliyet gösteren işletmelerin takip ettiği görülmektedir. 
Tablo 4. Konya il merkezinde faaliyet gösteren işletmelerin menülerinde yer alan çorba çeşitleri

\begin{tabular}{lllll}
\hline Çorbalar & \multicolumn{2}{l}{ Menüde var } & \multicolumn{2}{l}{ Menüde yok } \\
\hline Mercimek & $\mathrm{n}$ & $\%$ & $\mathrm{n}$ & $\%$ \\
Bamya & 42 & 70 & 18 & 30 \\
Arabaşı & 32 & 53,4 & 28 & 46,6 \\
İşkembe & 28 & 46,7 & 32 & 53,3 \\
Ezogelin & 13 & 21,7 & 47 & 78,3 \\
Yayla & 11 & 18,4 & 49 & 81,6 \\
Kelle-paça & 9 & 15 & 51 & 85 \\
Domates & 8 & 13,4 & 52 & 86,6 \\
Tandir & 2 & 3,4 & 58 & 96,6 \\
Kebap Ç. & 2 & 3,4 & 58 & 96,6 \\
Tarhun & 1 & 1,7 & 59 & 98,3 \\
Tavuk & 1 & 1,7 & 59 & 98,3 \\
Toyga & 1 & 1,7 & 59 & 98,3 \\
Beyran & 1 & 1,7 & 59 & 98,3 \\
Karalahana & 1 & 1,7 & 59 & 98,3 \\
Tuzlama & 1 & 1,7 & 59 & 98,3 \\
Damar & 1 & 1,7 & 59 & 98,3 \\
Tarhana & 1 & 1,7 & 59 & 98,3 \\
Sebze & 1 & 1,7 & 59 & 983 \\
Misir & 1 & 1,7 & 59 & 98,3 \\
Mahluta & 1 & 1,7 & 59 & 98,3 \\
Yeşil mercimek & 1 & 1,7 & 59 & 98,3 \\
\hline
\end{tabular}

Araştırma sonucunda tablo 4 incelendiğinde Konya iline özgü kabul edilen bamya, toyga, tarhana, mercimek, arabaşı, yayla ve tandır çorbalarının işletmelerin menülerinde yer aldığı görülmektedir. Bu çorbalar arasında en fazla mercimek, bamya, arabaşı ve yayla çorbasının menülerde bulunduğu tespit edilmiştir. Bu çorbalardan tarhana, mercimek, arabaşı ve yayla çorbası ülkemizde diğer illerde de tüketimi yaygın olan yöresel lezzetler arasında gösterilebilir. Konya'ya özgü olan diğer çorbaların ise (toyga, tarhana, tandır, tutmaç vb.) birçok işletmenin menüsünde bulunmadığı tespit edilmiştir. Yöresel çorba çeşitlerinden belli başlı çorbaların ön plana çıkarken diğerlerinin işletmeler tarafından çok fazla tercih edilmediği tespit edilmiştir. Çalışma sonuçlarına bakıldığında menülerde en çok bulunan çorbanın ezogelin çorbası olduğu sonucuna varılmıştır. Bu durumun başlıca sebebi birkaç gün önceden kalan mercimek çorbasının değerlendirilmesi olarak gösterilebilir. İşletmelerin \%10'undan fazlasında kelle paça ve işkembe çorbasının menülerde yer aldığı görülmektedir. Bu çorbalar Türkiye'deki neredeyse tüm illerde işletmelerin vazgeçilmez lezzetleri arasındadır.

Benzer çalışmalar incelendiğinde; Kızılırmak ve ark (2014)'nın Uzungöl'de yapmış oldukları çalışmada bölgeye özgü çorbalardan karalahana çorbası ve ısırgan çorbasına menülerde yer vermediği, yer veren işletmelerin ise yöresel olup olmadığına dair bir vurgu yapmadığı sonucuna ulaşılmıştır. Büyükşalvarcı ve ark (2016) Konya ilinde yapmış oldukları çalışmada yöresel çorbalardan en fazla $(\% 37,9)$ yoğurt çorbası ardından $(\% 31)$ arabaşı ve $(\% 24,1)$ bamya çorbasının menülerde yer aldığını bildirmişlerdir. Arıkan (2017) Eskişehir de yapmış olduğu çalışmada, Eskişehir'e özgü çorbalardan bamya, kuzu sorpa, tutmaç, kaşık börek ve erişteli mercimek çorbasının menülerde bulunduğunu bildirmiştir. Özel ve ark (2017) Kilis ilinde yapmış oldukları çalışmada işletmelerde Kilis ili yöresel çorbalarından sülüklü pancar ve kölük aş1 çorbasının bulunmadığını tespit etmişlerdir. Yöresel çorbalarda en fazla tatlı mahlıta $(\% 27,3)$ ve ekşili mahlıta $(\% 18,2)$ bulunduğunu belirtmişlerdir. Kılınç ve Kılınç (2018) Antalya ilinde yapmış olduğu çalışmada Türk mutfağına ait çorba çeşitlerinin işletmelerde $\% 22,71$ oranında yapılırken, yabancı ülkelere ait olan çorba çeşitlerinin ise \%77,29 oranında yapıldığını bildirmişlerdir. Erdem ve ark (2018) Mengen'in yöresel yemeklerini yiyecek ve içecek işletme sahiplerinin bilme durumu incelenmiştir. Katılımcıların yarısının yöresel çorbalardan bulgur 
çorbasını bildiklerini belirlemiş̧lerdir. Kurnaz ve İşlek (2018) tarafından Marmaris’te yapılan çalışmada bölgeye özgü çorbalardan sırasıyla en çok tavuk suyu çorbası, domatesli erişte, tarhana, soğan ve paça çorbasının menülerde bulunduğu belirlenmiştir. Yine bölgeye özgü olan ballı çorba, sütlü çorba ve pirinç çorbasının ise menülerde yer almadığı vurgulamıştır. Şen ve Silahşör (2018)'ün Erzincan ilinde yapmış olduğu çalışmada yöresel çorbaların araştırmaya katılan işletmelerin menülerinde yaklaşık \%50 oranında bulunduğunu bildirmişlerdir. $\mathrm{Bu}$ menülerde yöresel olarak en fazla üretilen çorba çeşidinin ise un çorbasi/kesme çorbası olduğunu belirlemişlerdir. Ceylan ve Güven (2018) Kütahya ilinde yapmış oldukları çalışmada Kütahya ili yöresel çorbalarının (miyane çorbası, oğmaç çorbası, kızılcık tarhana çorbası, sıkıcık çorbası, tutmaç çorbası) tüm işletme sahipleri tarafından bilindiği sonucuna ulaşmışlardır. Çorbaların tamamının işletmeciler tarafından bilinmesine rağmen menülerinde çok fazla yer verilmediğini vurgulamışlardır.

Yöresel ürünler üzerine yapılan çalışmaların genel olarak halk, işletme, işletmeciler, yerli ve yabancı turistler üzerine yapıldığı görülmüştür. Çalışmaların tamamına yakınında yöreye özgü olarak nitelendirilebilecek çorbaların işletmelerde fazla miktarda yapılmadığı, bölge insanı tarafından bilinirliğinin azaldığı ve yöreye gelen yerli ve yabancı turistlere işletmeler tarafından sunulmadığı tespit edilmiştir. İşletmeler genel olarak Türkiye'nin tamamında kabul görmüş ürünleri menülerine koyma isteği göstermektedir. Bu durum yöresel ürünlerin ve kültürün tanıtımını olumsuz etkilemektedir.

Tablo 5. Konya il merkezinde faaliyet gösteren işletmelerin menüsünde yer alan ana yemek çeşitleri

\begin{tabular}{lllll}
\hline Ana Yemek & \multicolumn{2}{l}{ Menüde var } & \multicolumn{2}{l}{ Menüde yok } \\
\hline & $\mathrm{n}$ & $\%$ & $\mathrm{~N}$ & $\%$ \\
\cline { 2 - 5 } Izgara çeşitleri & 27 & 45 & 33 & 55 \\
Firın Kebabı & 25 & 41,6 & 35 & 58,4 \\
Tirit & 18 & 30 & 42 & 70 \\
Kebap çeşitleri & 16 & 26,6 & 44 & 73,4 \\
Kuru Fasulye & 10 & 16,6 & 50 & 83,4 \\
Saç Kavurma & 9 & 15 & 51 & 85 \\
Beyti & 9 & 15 & 51 & 85 \\
Yap. Sarma (Etli) & 5 & 8,3 & 55 & 91,7 \\
İskender & 4 & 6,7 & 56 & 93,4 \\
Ekmek Salması & 3 & 5 & 57 & 95 \\
Patlıcan Orta (Bütümet) & 3 & 5 & 57 & 95 \\
Döner & 3 & 5 & 57 & 95 \\
Köfte & 3 & 5 & 57 & 95 \\
Tavuk Sote & 3 & 5 & 57 & 95 \\
Balık çeşitleri & 3 & 1,6 & 59 & 98,4 \\
Cağ Kebabı & 2 & 3,3 & 58 & 96,7 \\
Kuzu Güveç & 2 & 3,3 & 58 & 96,7 \\
Konya Tava & 2 & 3,3 & 58 & 96,7 \\
Etli Taze Fasulye & 2 & 3,3 & 58 & 96,7 \\
Etli Dolma & 2 & 3,3 & 58 & 96,7 \\
Karnıarık & 2 & 3,3 & 58 & 96,7 \\
Ciğer Tava & 1 & 1,6 & 59 & 98,4 \\
Mantı & 1 & 1,6 & 59 & 98,4 \\
Kayısılı Yahni & 1 & 1,6 & 59 & 98,4 \\
Erikli Yahni & 1 & 1,6 & 59 & 98,4 \\
Ekşili Su Kabağı & 1 & 1,6 & 59 & 98,4 \\
Nohut & 1 & 1,6 & 59 & 98,4 \\
Tavuklu Pilav & 1 & 1,6 & 59 & 98,4 \\
Tantuni & 1 & 1,6 & 59 & 98,4 \\
Abagannuş & 1 & 1,6 & 59 & 98,4 \\
\hline
\end{tabular}


Araştırma sonuçlarına göre tablo 5 incelendiğinde Konya iline özgü kabul edilen firın kebabı, tirit, etli yaprak sarma, ekmek salması, patlıcan orta yemeklerinin işletmelerde yapıldığ 1 görülmüştür. Bu yemekler arasında sırasıyla en fazla firın kebabı ve tirit menüde yer almaktadır. Konya'ya özgü olan diğer yemeklerin ise (ekmek salması, patlıcan orta (bütümet), kayısılı yahni, erikli yahni, etli yaprak sarma) gibi çeşitlerin birçok işletmede satışa sunulmadığı tespit edilmiştir. $\mathrm{Bu}$ durum yöresel belli başlı ana yemeklerin ön plana çıkarken diğerlerinin esnaf lokantaları tarafından çok fazla tercih edilmediğini göstermiştir. Izgara çeşitleri, menülerde en fazla yer alan ana yemek olarak göze çarpmaktadır. Bu durumun ise Türkiye'nin neredeyse her ilinde 1zgara çeşitlerinin çok fazla tüketilmesinden kaynaklandığı düşünülmektedir.

Benzer çalışmalar incelendiğinde; Kızılırmak ve ark (2014) Uzungöl'de yapmış oldukları çalışmada Uzungöl yöresel yemeklerinden kuymak (12), alabalık (11) ve mıhlamanın (10) en çok tercih edilen yemekler olduğu sonucuna ulaşmışlardır. İşletmelerin büyük bölümünde yöresel yemeklerin gösterildiği bölümlerin olmadığını vurgulamışlardır. Büyükş̧alvarcı ve ark (2016) Konya da yapmış oldukları çalışmada Konya ili yöresel yemeklerinden en fazla et tiridi ve furın kebabına $(\% 65,5)$ menülerde yer verildiği sonucuna ulaşmışlardır. Konya'ya özgü diğer yemeklerin ise çok az işletmenin menüsünde yer aldığını belirlemişlerdir. Arıkan (2017) Eskişehir ilinde yapmış olduğu çalışmada Eskişehir yöresel yemeklerinden balaban köftenin işletme menülerinde en çok karşılaşılan yemek olduğunun sonucuna ulaşmıştır. Özel ve ark (2017) Kilis ilinde yapmış oldukları çalışmada Kilis ili yöresel yemeklerinden Kilis tava yemeğinin işletmelerin hepsinin menüsünde olduğunu belirtmişlerdir. Büyük bir çoğunluğunda ise $(\% 81,8)$ Kilis kebabı, lebeniye, oruk ve sucuk hamra ana yemeklerinin bulunduğu ancak eğeği dolması, çürütme et, et balığı ve bulamaç yöresel yemeklerinin hiçbir işletmede bulunmadığı sonucuna ulaşmışlardır. Kılınç ve Kılınç (2018) Antalya il merkezinde yapmış oldukları çalışmada yiyecek gruplarında yabancı mutfak ürünlerinin ulusal mutfak ürünlerinden daha fazla olduğunu tespit etmişlerdir. Türk mutfağına ait ana yemek çeşitlerinin işletmelerde $\% 24,46$ oranında yapılırken, yabancı ülkelere ait olan ana yemek çeşitlerinin ise $\% 71,83$ oranında yapıldığını bildirmişlerdir. Erdem ve ark (2018) Mengen ilçesinde yapmış oldukları çalışmada Mengen'e ait yöresel yemeklerin (keşli erişte, kaldırık dolması) işletmelerin yarısı tarafından bilindiği ve işletmeleri \%62,5 'i tarafından menüde yer verildiği sonucuna ulaşmışlardır. Kurnaz ve İşlek (2018) Marmaris de yapmış oldukları çalışmada işletmelerin menülerinde yer alan ana yemeklerin çorba, tatlı ve reçellere göre nispeten daha fazla yer aldığı sonucuna ulaşmışlardır. Menülerde en çok deniz ürünleri yemekleri olduğunu vurgulamışlardır. Şen ve Silahşör (2018) Erzincan'da yapmış oldukları çalışmada Erzincan ili yöresel yemeklerinin işletmelerin yarıya yakınında menülerde olduğu sonucuna ulaşmışlardır. Başta gelen yemekler ise etli yaprak sarma döner ve su böreği (etli) olarak belirtilmiştir. Ceylan ve Güven (2018) yapmış oldukları çalışmada Kütahya ili yöresel yemeklerinden lahana sarması, mercimekli pilav ve cimcik mantısının işletmeciler tarafından bilindiği fakat menülerinde çok fazla yer verilmediği sonucuna ulaşmışlardır.

Yöresel ürünler üzerine yapılan çalışmaların halk, işletme, işletmeciler, yerli ve yabancı turistler üzerine yapıldığı tespit edilmiştir. Genellikle özgün kabul edilen yemeklerin ön plana çıktığı, diğer yöresel yemeklerin fazla üretilmediği görülmüştür. Herhangi bir yöreyi ziyaret eden yerli ve yabancı turistlere işletmelerin genellikle yöreye has lezzetleri sunmadığı yapılan çalışmalar sonucu tespit edilmiştir. Ayrıca çalışmalarda yöre insanı tarafından yöresel ürünlerin unutulmaya başladığ 1 kanısına varılmıştır. Yöresel mutfağın tanıtımında işletmelerin yetersiz kaldığı konusunda tespitler yapılmıştır. Bu durum yöresel ürünlerin giderek azalmaya başladığının bir göstergesidir. 
Tablo 6. Konya il merkezinde faaliyet gösteren işletmeler menülerinde yer alan firın ürünleri

\begin{tabular}{lllll}
\hline Fırın Ürünleri & \multicolumn{2}{l}{ Menüde Var } & \multicolumn{2}{l}{ Menüde Yok } \\
\hline & $\mathrm{n}$ & $\%$ & 21 & $\%$ \\
\cline { 2 - 5 } Etliekmek & 39 & 65 & 28 & 46,7 \\
Bıçak Arası & 32 & 53,3 & 42 & 70 \\
Peynirli Börek & 18 & 30 & 43 & 71,7 \\
Karışı & 17 & 28,3 & 49 & 81,7 \\
Lahmacun & 11 & 18,3 & 53 & 88,4 \\
Konya Böreği & 7 & 11,6 & 53 & 88,4 \\
Kaşarlı Börek & 7 & 11,6 & 53 & 88,4 \\
Kekikli & 7 & 11,6 & 54 & 90 \\
Yağ Somunu & 6 & 10 & 55 & 91,7 \\
Karışık Börek & 5 & 8,3 & 55 & 91,7 \\
Karyağdı & 5 & 8,3 & 58 & 96,7 \\
Kaşarlı Pide & 2 & 3,3 & 58 & 96,7 \\
Küflüce & 2 & 3,3 & 58 & 96,7 \\
Küflü P. Börek & 2 & 3,3 & 58 & 96,7 \\
Recai & 2 & 3,3 & 59 & 98,4 \\
Su Böreği (etli) & 1 & 1,6 & 59 & 98,4 \\
Bafra Kıymalı Pide & 1 & 1,6 & 59 & 98,4 \\
Kuşbaşılı Pide & 1 & 1,6 & 59 & 98,4 \\
Pastırmalı Pide & 1 & 1,6 & 59 & 98,4 \\
Kavurmalı Pide & 1 & 1,6 & 59 & 98,4 \\
Fıstıklı Etliekmek & 1 & 1,6 & 59 & 98,4 \\
Kavurmalı Börek & 1 & 1,6 & 59 & 98,4 \\
Saraylım & 1 & 1,6 & 59 & 98,4 \\
Tosunum & 1 & 1,6 & 59 & 98,4 \\
Tereyağlı Börek & 1 & 1,6 & & \\
Tavuklu Pide & 1 & 1,6 & & 59 \\
\hline
\end{tabular}

Araştırma sonuçlarına göre tablo 6 incelendiğinde Konya iline özgü kabul edilen etliekmek, bıçakarası, peynirli börek ve karışık börek fırın ürünlerinin işletmelerde üretildiği görülmüş̧ür. $\mathrm{Bu}$ ürünler arasında en çok etliekmek ve bıçakarası üretilmektedir. Konya'nın sembolü haline gelmiş bir firın ürünü olan etliekmek Konya il merkezinde en çok üretilen yemek olmuştur. Konya iline özgü olan diğer firın ürünlerinin ise (küflü peynirli börek, recai, yăg somunu, su böreği (etli) birç̧ok işletmede satışa sunulmadığı görülmüştür. Bu durumda yöresel belli başlı fırın ürünlerinin ön plana çıkarken diğerlerinin esnaf lokantaları tarafından çok fazla yapılmadığı tespit edilmiştir. Özellikle Konya ilinde evlerde çok sık yapılan etli su böreğinin işletmelerin yalnızca bir tanesinde üretildiği sonucuna ulaşılmıştır. Bu durum geleneksel Konya mutfağının yerli ve yabancı turiste tam anlamıyla yansitılamadığı sonucunu doğurmaktadır. Ayrıca su böreği yapımının deneyim ve zahmet gerektirdiği için işletmelerin fazla tercih etmediği düşünülebilir.

Benzer çalışmalar incelendiğinde; Aydemir ve Özdemir (2014) yaptıkları çalışmada Yenipazar' da pide sunan yerel yiyecek-içecek işletmelerinin 'Yavaş Yemek Hareketi' misyonuna uygun davrandıkları sonucuna ulaşmıştır. Arıkan (2017) yapmış olduğu çalışmada Eskişehir ilinde faaliyet gösteren işletmelerin menülerinde en az 3 çeşit, en fazla 32 çeşit pide bulunduğunu, genel olarak işletmelerde ise 12-14 arası pide çeşidinin bulunduğunu bildirmiştir. Bu araştırma sonuçları ile karşılaştırıldığında firın ürünlerinin üretiminin oldukça fazla olduğu ve müşteriler tarafından talep gördüğü sonucu çıkarılmıştır. 
Tablo 7. Konya il merkezinde faaliyet gösteren işletmelerde üretilen salata, meze çeşitleri

\begin{tabular}{|c|c|c|c|c|}
\hline \multirow[t]{2}{*}{ Salata ve Meze } & \multicolumn{2}{|c|}{ Menüde var } & \multicolumn{2}{|c|}{ Menüde yok } \\
\hline & $\mathrm{n}$ & $\%$ & $\mathrm{n}$ & $\%$ \\
\hline Acılı Ezme & 35 & 58,3 & 25 & 41,7 \\
\hline Çoban Salata & 33 & 55 & 27 & 45 \\
\hline Mevsim Salata & 26 & 43,3 & 34 & 56,7 \\
\hline Yoğurt & 19 & 31,6 & 41 & 68,4 \\
\hline Kaşık Salata & 13 & 21,6 & 47 & 78,4 \\
\hline Gavurdağı Salata & 9 & 15 & 51 & 85 \\
\hline Şef Salata & 9 & 15 & 51 & 85 \\
\hline Yeşil Salata & 5 & 8,3 & 55 & 91,7 \\
\hline Haydari & 4 & 6,6 & 56 & 93,7 \\
\hline Roka Salata & 4 & 6,6 & 56 & 93,7 \\
\hline Köz Patlıcan & 3 & 5 & 57 & 95 \\
\hline Közlenmiş Soğan & 3 & 5 & 57 & 95 \\
\hline Cacık & 3 & 5 & 57 & 95 \\
\hline Akdeniz Salata & 3 & 5 & 57 & 95 \\
\hline Sezar Salata & 3 & 5 & 57 & 95 \\
\hline Turp & 2 & 3,3 & 58 & 96,7 \\
\hline Ton Balıklı Salata & 2 & 3,3 & 58 & 96,7 \\
\hline Kirma Salata & 2 & 3,3 & 58 & 96,7 \\
\hline Kaşarlı Mantar & 2 & 3,3 & 58 & 96,7 \\
\hline Ege Salata & 1 & 1,6 & 59 & 98,4 \\
\hline Y. Marul Salata & 1 & 1,6 & 59 & 98,4 \\
\hline Nurdağı Salata & 1 & 1,6 & 59 & 98,4 \\
\hline Y. Semizotu & 1 & 1,6 & 59 & 98,4 \\
\hline Rus Salatası & 1 & 1,6 & 59 & 98,4 \\
\hline
\end{tabular}

Araştırma sonuçlarına göre tablo 7 incelendiğinde Türkiye genelinde tüketilen acılı ezme, çoban salata, mevsim salata ürünlerinin işletmelerde en çok yapılan salata ve meze çeşitleri olduğu görülmüştür. Türkiye'nin hemen her bölgesinde tüketilen meze çeşitlerinin Konya ilinde faaliyet gösteren işletmelerin menülerinde de yer aldığı tespit edilmiştir.

Benzer çalışmalar incelendiğinde Kılınç ve Kılınç (2018) tarafindan Antalya ilinde Türk ve yabancı mutfak ürünleri üzerine yapılan çalışmada; Türk mutfağına ait salata çeşitlerinin işletmelerde $\% 21,34$ oranında yapılırken, yabancı ülkelere ait olan salata çeşitlerinin ise $\% 77,17$ oranında yapıldığını tespit etmiş̧lerdir. Kurnaz ve İşlek tarafından (2018) Marmaris'te yapılan çalışmada en fazla deniz börülcesi ve taze iç bakla salatasının menülerde yer aldığı tespit edilmiştir.

Yöresel ürünler hakkında yapılan çalışmalar incelendiğinde Türk mutfağında tüm yörelerde yapılan salata ve meze (çoban salata, cacık, haydari) çeşitlerinin menülerde yer aldığ yöresel olarak yapılan salata ve meze çeşitlerinin ise menülerde az yer aldığı sonucuna ulaşılmıştır. 
Tablo 8. Konya il merkezinde faaliyet gösteren işletmelerin menülerinde yer alan içecek çeşitleri

\begin{tabular}{lllll}
\hline İçecekler & \multicolumn{2}{l}{ Menüde var } & \multicolumn{2}{l}{ Menüde yok } \\
\hline \multirow{2}{*}{ Kola } & $\mathrm{n}$ & $\%$ & $\mathrm{n}$ & $\%$ \\
Ayran & 60 & 100 & 0 & 0 \\
Soda & 60 & 100 & 0 & 0 \\
Şalgam & 60 & 100 & 0 & 0 \\
Fanta & 60 & 100 & 0 & 0 \\
Gazoz & 60 & 100 & 0 & 0 \\
Meyve Suyu & 60 & 100 & 0 & 0 \\
Çay & 60 & 100 & 0 & 0 \\
Türk Kahvesi & 60 & 100 & 0 & 0 \\
Yayık Ayran & 60 & 100 & 0 & 0 \\
Nar Suyu & 1 & 3,3 & 58 & 96,7 \\
Portakal Suyu & 1 & 1,6 & 59 & 98,4 \\
Demir & 1,6 & 59 & 98,4 \\
Şerbeti & 1 & 1,6 & 59 & 98,4 \\
Limonata & 1 & 1,6 & 59 & 98,4 \\
\hline
\end{tabular}

Araştırma sonuçlarına göre tablo 8 incelendiğinde işletmelerde sunulan içeceklerde işletmelerin tamamında hazır olarak işletmede sunulan içecekler tercih edildiği görülmüştür. İşletmelerin çok az bir kısmında yöresel içeceklerin (Ayran, şerbetler vb) satışa sunulduğu tespit edilmiştir. Bu durum işletmelerin içeceklerini kendileri üretmek yerine dışarıdan temin ettikleri sonucunu göstermektedir. Yöresel içeceklerin işletmelerde menülerde yer bulamaması birçok yöresel nitelikteki içeceğin zamanla unutulacağını göstermektedir. İşletmelerin tamamında gazlı içecek satışlarının yapıldığı ve bu durumun taleple ilgili olduğu tahmin edilmektedir.

Benzer çalışmalar incelendiğinde; Kılınç ve Kılınç (2018) Antalya ilinde yapmış olduğu çalışmada Türk mutfağına ait içecek çeşitlerinin işletme menülerinde $\% 15,51$ oranında sunulduğunu, yabancı ülkelere ait olan içecek çeşitlerinin ise \%84,42 oranında sunulduğunu bildirmiştir. Bu araştırmadan da anlaşılacağı üzere yöresel lezzetlerin dönem içinde tüketimi azalmasından dolayı veya işletmelerin yöresel ürünlerdeki karlılık oranının düşük olmasından dolayı menülerde fazla yer bulamadığı görülmektedir. 
Tablo 9. Konya il merkezinde faaliyet gösteren işletmelerin menülerinde yer alan tatlı çeşitleri

\begin{tabular}{lllll}
\hline Tatlı & \multicolumn{2}{l}{ Menüde var } & \multicolumn{2}{l}{ Menüde yok } \\
\hline & $\mathrm{n}$ & $\%$ & $\mathrm{n}$ & $\%$ \\
\cline { 2 - 5 } Künefe & 25 & 41,6 & 35 & 58,4 \\
Saç Arası & 24 & 40 & 36 & 60 \\
Höşmerim & 19 & 31,6 & 41 & 68,4 \\
Sütlaç & 16 & 26,6 & 44 & 73,4 \\
Firın Sütlaç & 14 & 23,3 & 46 & 76,7 \\
Ekmek Kadayıfi & 9 & 15 & 51 & 85 \\
Kabak Tatlısı & 5 & 8,3 & 55 & 91,7 \\
İrmik Helvası & 5 & 8,3 & 55 & 91,7 \\
Baklava & 5 & 1,6 & 59 & 98,4 \\
Kadayıf çeşitleri & 4 & 3,3 & 58 & 96,7 \\
Katmer & 2 & 3,3 & 58 & 96,7 \\
Triliçe & 2 & 3,3 & 58 & 96,7 \\
Güllaç & 1 & 1,6 & 59 & 98,4 \\
Laz Böreği & 1 & 1,6 & 59 & 98,4 \\
Ekmek Kadayıfi & 1 & 1,6 & 59 & 98,4 \\
Ayva Tatlısı & 1 & 1,6 & 59 & 98,4 \\
Güllaç & 1 & 1,6 & 59 & 98,4 \\
Kazandibi & 1 & 1,6 & 59 & 98,4 \\
Limonlu Sorbe & 1 & 1,6 & 59 & 98,4 \\
Revani & 1 & 1,6 & 59 & 98,4 \\
Tulumba & 1 & 1,6 & 59 & 98,4 \\
Zerde & 1 & 1,6 & 59 & 98,4 \\
\hline
\end{tabular}

Araştırma sonuçlarına göre Tablo 9 incelendiğinde Konya iline özgü kabul edilen sacarası, sütlaç höşmerim tatılarının işletmelerin \%30'undan fazlasınını menüsünde yer aldığı tespit edilmiştir. Konya iline özgü olan diğer tatlılardan ekmek kadayıfı, zerde, ayva tatlısı ve irmik helvasının ise birçok işletmede satışa sunulmadığı görülmüştür. Bu durumda yöresel belli başlı tatlıların ön plana çıkarken diğerlerinin esnaf lokantaları tarafindan çok fazla tercih edilmediği tespit edilmiştir. Künefe ise Konya mutfağına ait olmamasına rağmen birçok işletmede tüketime sunulmaktadır. Bu durumun sebebinin ise donuk ürün olarak işletmelerde uzun zaman muhafaza edilebilmesinden kaynaklanmaktadır.

Benzer çalışmalar incelendiğinde; Kızılırmak ve ark (2014) Uzungöl ilçesinde yapmış oldukları çalışmada işletmelerden 8 tanesinin firın sütlaca yer verdiğini ancak menülerde tatlılar bölümünde yöresel olup olmadığıyla ilgili bir vurgu yapılmadığı sonucuna ulaşmışlardır. Büyükşalvarcı ve ark (2016) yapmış oldukları çalışmada Konya ili yöresel tatlılarının menüde yer almasına göre en çok sacarası $(\% 65,5)$ ikinci sırada ise höşmerim $(\% 37,9)$ bulunduğunu bildirmişlerdir. Arıkan (2017) Eskişehir ilinde yapmış olduğu çalışmada işletme menülerinde en fazla 27, en az 2 genelde ise 8-10 tatliya yer verildiğini Eskişehir ve köylerinde pişirilen kabak tatlısının menülerde en çok yer alan tatlı olduğunu, sarı burma ve Sivrihisar baklavasının menülerde yer almadığını vurgulamıştır. Bazı yöresel tatlılara ise menülerde hiç yer verilmediğini vurgulamışlardır. Özel ve ark (2017) Kilis ilinde yapmış oldukları çalışmada Kilis ili yöresel tatlllarından olan Kilis katmeri $(\% 81,8)$ ve cennet çamurunun $(\% 72,7)$ işletmelerin büyük çoğunluğunun menülerinde yer aldığı ancak haytayla, şüdüt ve sucuk haspsesi tatlılarının işletmelerde bulunmadığı sonucuna ulaşmışlardır. Erdem ve ark (2018) Mengen de yapmış oldukları çalışmada Mengen yöresel tatılarından olan höşmerimin işletmeciler tarafından bilindiği ve menülerinde yer verildiği sonucuna ulamışlardır. Kurnaz ve İşlek (2018) Marmaris de yapmış oldukları çalışmada Marmaris yöresel tatlı ve reçellerinin menülerde en az yer alan bölüm olduğu sonucuna varmışlardır. İşletmelerde en çok yer alan tatlının sütlaç olduğunu bunu sırasıyla kabak besteli, çıtırmak, bestel, portakal reçelinin takip ettiğini ancak darı helvası, Marmaris kurabiyesi gibi tatıların menülerde yer almadığını vurgulamışlardır. Şen ve Silahşör 
(2018) Erzincan ilinde yapmış oldukları çalışmada işletmelerin yarısından fazlasının menülerinde Erzincan ili yöresel tatlılarına yer verildiği sonucuna ulaşmışlardır. Başta gelen yöresel tatlıların kasefe ve kabak tatlısı olduğunu vurgulamışlardır. Ceylan ve Güven (2018) Kütahya ilinde yapmış oldukları çalışmada işletmeciler tarafından Kütahya yöresel tatlılarından olan irmik helvası ve namaz lokmasının bilindiğini ancak doldurma kabak tatlısının bilinirliğinin az olduğu sonucuna ulaşmışlardır.

Yapılan çalışmaların incelendiğinde çalışmaların tamamına yakınında yöresel tatlıların işletmelerde üretilmediği, bölge insanı tarafından unutulmaya başlandığı tespiti yapılmıştır. Yöreyi ziyarete gelen yerli ve yabancı turistlere işletmeler tarafından sunulmadığı gözlenmiştir. İşletmeler genel olarak Türkiye'nin tamamında kabul görmüş ürünleri menülerine koyma isteği göstermektedir. $\mathrm{Bu}$ durum yöresel tatlıların bilinirliğinin eskisi kadar olmadığının bir göstergesidir.

\section{Sonuç ve Öneriler}

Türk mutfağı dünyada önde gelen mutfaklar arasında yerini almıştır. Gastronomi turizmi özellikle 2000 yılından sonra hızlı bir gelişim göstermiş̧tir. Bu gelişimde yöresel mutfakların etkisi yadsınamaz. Toplumda yaşayan insanların kültürünü yansitan ilk etmen kuşkusuz yemek kültürüdür. Yemek kültürünün ayakta kalması, unutulmaması başta toplum olmak üzere birçok etkene bağlıdır. Bu etkenlerden en önemlisi şüphesiz yiyecek-içecek hizmeti sunan işletmelerdir.

Araştırma sonucunda; çalışmaya dâhil olan işletmelerin \%50'sinde 10 'dan fazla eleman çalıştırdığ görülmektedir. Bu özelliği ile işletmelerin genelinin orta ve üst düzey işletme olduğunu söylenebilir. İşletmelerin \%41'i kebap ve etliekmek salonu özelliğini taşırken yaklaşık \%27'si yöresel mutfak olan Konya mutfağı üzerine çalışmaktadır. Araştırmada çorba kategorisinde yapılan inceleme sonucunda mercimek, bamya ve arabaşı çorbalarının işletmelerin çoğunda üretildiği görülmüştür. İşletmelerde belli başlı çorbalar dışında yöresel çorbalara daha fazla önem verilmesi gerekmektedir. Bu çorbalar içerisinde özellikle tandır, tutmaç ve tarhana çorbasının bulunması önem taşımaktadır. Ana yemek kategorisinde Konya iline özgü olan firın kebabı, tirit ve etliekmek çeşitlerinin birçok işletmede üretildiği tespit edilmiştir. Ancak yine Konya iline özgü olan ekmek salması, patlıcan orta (bütümet), kayısılı yahni ve erikli yahni gibi yöre mutfağına has lezzetlerin ise neredeyse hiç yapılmadığı görülmüştür. Ana yemek olarak ön plana çıkan fürun kebabı ve etliekmek gibi ürünlerden ziyade özellikle bütümet ve kayısılı yahni gibi yemeklerin yiyecek içecek işletmelerinde (esnaf lokantaları, oteller) yapılması gerekmektedir. Konya gastronomisinin gelişmesi ve yöresel yemeklerin menülerde daha çok yer alması için yöresel ürünlere daha fazla yer verilmesi büyük önem taşımaktadır. Konya firın ürünlerinde önemli merkezler arasındadır. Özellikle etliekmek, iki bıçak arasında kesilerek hazırlanan bıçakarası, küflü peynirli börek, peynirli börek ve Mevlâna böreği Türkiye'de Konya mutfağına mal olmuş önemli değerler olarak ön plana çıkmaktadır. Fırın ürünleri kategorisinde Konya'ya mal olmuş ürünlerin nerdeyse tamamı birçok işletmede üretilmektedir. Ancak bu ürünlerin aslına uygun olarak yapılması ve sunulmasına işletmeler tarafından dikkat edilmeli ve bir denetim mekanizması kurulmalıdır. Meze ve salata yönünden Konya mutfağının nispeten zayıf olduğu söylenebilir. Bu yüzden Türkiye'nin tamamında kabul görmüş olan ezme, çoban salata ve mevsim salata gibi ürünler işletmelerde daha fazla sunulmaktadır. Meze ve salata olarak Konya mutfağının önemli lezzetlerinden olan güneyik (Konya'ya özgü bir ot) salatası ve cacık gibi ürünlerinde menülerde bulunması gerekmektedir. Araştırma kapsamında incelenen işletmelerde sunulan içeceklerin çoğunluğunun gazlı içeceklerden oluştuğu görülmüştür. Oysa Konya mutfağı özellikle şerbetler ve hoşaf tarzı içecekler bakımından önemli bir konumdadır. Dolayısıyla bu içecekler menüde yer almalı ve yerli-yabancı turistin tatmasına, tanımasına öncelik verilmelidir. İşletmelerde yapılan tatlılar incelendiğinde yerli tatlılar olan höşmerim, sacarası ve sütlaç bol miktarda menülerde yer alırken, zerde, ayva tatlısı, ekmek kadayıfı (vişneli tirit) yöresel olmasına rağmen menülerde yer almamaktadır. 
Çalışma sonucunda yöresel mutfağa özgü olan lezzetlerin çok az kısmının menülerde yer aldığı geniş bir kısmının ise menülerde yer almadığı görülmektedir. Bu durum özellikle Konya'ya gelen yerli ve yabancı turistlere yöresel mutfağın tanıtımında sınırlılıklar oluşturmaktadır. $\mathrm{Bu}$ sınırlılıkların ortadan kaldırılması için sivil toplum kuruluşları, belediyeler ve işletme sahipleri bir bütün olarak hareket etmeli ve kentin gastronomi kentine dönüşmesi için çaba göstermelidir. Yöresel mutfağa olan ilginin artması için Kamu Kurumları ve Üniversite iş birliğiyle birlikte tanıtımlar yapılmalı ve etkinlikler düzenlenmelidir. Konya ilini ziyarete gelen yerli ve yabancı turistlere ziyaret ettikleri bölgelerde Konya mutfağını tanıtmak amacıyla hazırlanmış bir broşür dağıtılarak bilgilendirme yapılabilir. İşletmelerin menülerinde özellikle yöresel yemeklerin yer aldığ 1 kısım ayrıca belirtilerek yemeklerin yan tarafına açıklayıcı bilgiler verilmelidir. Konya mutfağını tanıtmak amacıyla unutulan veya unutulmaya yüz tutmuş yemeklerin yeniden halka tanıtılabileceği kurslar açılması önem taşımaktadır. Sadece halk değil Konya ilinde faaliyet gösteren işletmede çalışanlarında bu kurslara katılması gerekmektedir. Gastronomi festivallerinin sayısının her geçen gün artması festivallerin kentin gelişimine katkı sağladığı şeklinde yorumlanabilir. Bu nedenle Konya ilinde yöresel yemekleri ön plana çıarabilecek nitelikte festivaller düzenlenmeli ve ulusal medyada yer edinmelidir.

\section{Kaynakça}

Aksoy, M., Akbulut, A. B. ve İflazoğlu, N. (2016). Mevlevilikte mutfak kültürü ve ateşbaz-1 veli makam1. Journal of Tourism and Gastronomy Studies, 4(1), 96-103.

Alptekin A. (2007). Konya mutfağı (Yüksek lisans tezi). Dumlupınar Üniversitesi, Kütahya.

Arıkan, A.D. (2017). Eskişehir'deki yiyecek içecek işletmelerinin menülerinde Eskişehir mutfağının yeri. Journal of Human Sciences, 14(2), 2061-2077.

Aslan, Z., Güneren, E., ve Çoban, G. (2014). Destinasyon markalaşma sürecinde yöresel mutfağın rolü: Nevşehir örneği. Journal of Tourism and Gastronomy Studies, 2(4), 3-13.

Bekleyiciler, N. (2007). Ateşbaz-ı Veli. Konya: Dizgi Ofset

Büyükşalvarcı, A., Şapcılar, M.C., ve Yılmaz, G. (2016). Yöresel yemeklerin turizm işletmelerinde kullanılma durumu: Konya örneği. Journal of Tourism and Gastronomy Studies, 4(4), 165-181.

Ceylan, A. ve Güven, Ö. Z. (2018). Yiyecek içecek işletmelerinin menü planlamasında Kütahya’nın yöresel yemeklerinin yeri üzerine bir araştırma. Journal of Tourism and Gastronomy Studies, 6(3), 451-459.

Cömert, M. (2014). Turizm pazarlamasında yöresel mutfakların önemi ve Hatay mutfağ örneği. Journal of Tourism and Gastronomy Studies, 2(1), 64-70.

Cömert, M. ve Özata, E. (2016). Tüketicilerin yöresel restoranları tercih etme nedenleri ve Karadeniz mutfağı örneği. Journal of International Social Research, 9(42), 1963-1973.

Erdem, Ö., Mızrak, M., ve Kemer, A.K. (2017). Yöresel yemeklerin bölge restoranlarında kullanılma durumu: Mengen örneği. In 1st International Sustainable Tourism Congress Proceedings Book (pp. 18-33).

Ertaş, M., Bulut-solak, B. ve Kılınç, C. Ç. (2017). Konya'da Mevlevi mutfağ yiyeceklerinin gastronomi turizminde canlandırılması. Gazi Üniversitesi Turizm Fakültesi Dergisi, 1(1), 52-70.

Halıcı, N. (2008). Tandır değil firın kebabı. Konyalife Dergisi, 17, 118.

Hatipoğlu, A., Zengin, B., Batman, O., ve Şengül, S. (2013). Yöresel yemeklerin, kırsal turizm işletmeleri mönülerinde kullanım düzeyleri: Gelveri örneği, Uluslararası Sosyal ve Ekonomik Bilimler Dergisi, 3(1), 6-11.

Iş1k, A. (2006). Konya mutfak kültürü ve Konya yemekleri. Konya: Damla Ofset

İslamoğlu, A.H. Alnıaçık, Ü. (2016). Sosyal bilimlerde araştırma yöntemleri. İstanbul: Beta 
Kılınç, O. ve Kılınç, U. (2018). Yöresel Gastronomik değerlerin ürüne dönüşme düzeyi: Antalya il merkezi. Journal of Tourism and Gastronomy Studies, 6(3), 394-410.

Kızılırmak, İ, Albayrak, A. ve Küçükali, S. (2014). Yöresel mutfağın kırsal turizm işletmelerinde uygulanması: Uzungöl örneği. Uluslararası Sosyal ve Ekonomik Bilimler Dergisi, 4 (1), 75-83.

Kurnaz, A. ve İşlek, E. (2018). Yöresel yemeklerin restoranlar tarafından kullanımının değerlendirilmesi: Marmaris örneği. Uluslararası Sosyal ve Ekonomik Bilimler Dergisi, 8(1), 5059.

Mehmet, Ö. (1971). Mevlâna şehri Konya. Konya: Konya Valiliği

Mil, B. ve Denk, E. (2015). Erzurum mutfağı yöresel ürünlerin otel restoran menülerinde kullanım düzeyi: Palandöken örneği. Uluslararası Sosyal ve Ekonomik Bilimler Dergisi, 5(2), 1-7.

Odabaşı, S. (2001). 20. Yüzyıl başlarında Konya’nın görünümü. Konya: T.C Konya Valiliği İl Kültür Müdürlüğü.

Odabaş1, S. (2001). Konya mutfak kültürü. Konya: Konya Ticaret Odası.

Ögel, B. (1978). Türk kültür tarihine giriş. Ankara: Kültür Bakanlığı Yayınları.

Özel, G., Yıldız. F., ve Akbaba, M. (2017). Yöresel yemeklerin restoran menülerinde yer alma düzeyinin belirlenmesi: Kilis mutfağı örneği. Kesit Akademi Dergisi, 11(3), 351-364.

Özkafa, A. (2010). Gonya kitabı. Konya: Memleket yayınevi.

Seçim, Y. (2018). Yöresel bir ürün olan Konya etliekmeği ve genel özellikleri hakkında nitel bir çalışma. Journal of Tourism and Gastronomy Studies 6(4), 197-209.

Seyitoğlu, F. ve Çalışkan, O. (2014). Turizm literatüründe Türk mutfağı üzerine yapılan araştırmaların değerlendirilmesi. Journal of Tourism and Gastronomy Studies, 2(4), 23-35.

Şen, N. Ve Silahşör, Y. (2018). Gastronomi turizmi kapsamında Erzincan ili yiyecek içecek işletmelerinde sunulan yöresel yemekler üzerine bir araştırma. Güncel Turizm Araştırmaları Dergisi, 2(Ek1), 414-429.

Yeşilyurt, A.G.H., Yeşilyurt, A.G.C., Güler, A.G.O., ve Özer, Ö.G.S. (2017). Otel işletmelerinin menülerinde yöresel yemek kültürünü yaşatmak: Adıyaman örneği. Internatıonal West Asıa Congress Of Tourism (Iwact'17) TheBook Of Full-Text (P. 173)

Zağralı, E. ve Akbaba, A. (2015). Turistlerin destinasyon seçiminde yöresel yemeklerin rolü: İzmir Yarımadası'nı ziyaret eden turistlerin görüşleri üzerine bir araştırma. Journal of Yaşar University, 10(40), 6633-6644.

\section{ETIKK ve BİLIMSEL İLKELER SORUMLULUK BEYANI}

$\mathrm{Bu}$ çalışmanın tüm hazırlanma süreçlerinde etik kurallara ve bilimsel atıf gösterme ilkelerine riayet edildiğini yazar(lar) beyan eder. Aksi bir durumun tespiti halinde Afyon Kocatepe Üniversitesi Sosyal Bilimler Dergisi'nin hiçbir sorumluluğu olmayıp, tüm sorumluluk makale yazarlarına aittir. 